\title{
Evaluating the accuracy of soil water sensors for irrigation scheduling to conserve freshwater
}

\author{
Girisha K. Ganjegunte • Zhuping Sheng • \\ John A. Clark
}

Received: 31 August 2011/Accepted: 2 February 2012/Published online: 21 February 2012

(C) The Author(s) 2012. This article is published with open access at Springerlink.com

\begin{abstract}
In the Trans-Pecos area, pecan [Carya illinoinensis (Wangenh) C. Koch] is a major irrigated cash crop. Pecan trees require large amounts of water for their growth and flood (border) irrigation is the most common method of irrigation. Pecan crop is often over irrigated using traditional method of irrigation scheduling by counting number of calendar days since the previous irrigation. Studies in other pecan growing areas have shown that the water use efficiency can be improved significantly and precious freshwater can be saved by scheduling irrigation based on soil moisture conditions. This study evaluated the accuracy of three recent low cost soil water sensors $\left(\mathrm{ECH}_{2} \mathrm{O}-5 \mathrm{TE}\right.$, Watermark 200SS and Tensiometer model R) to monitor volumetric soil water content $\left(\theta_{\mathrm{v}}\right)$ to develop improved irrigation scheduling in a mature pecan orchard in El Paso, Texas. Results indicated that while all three sensors were successful in following the general trends of soil moisture conditions during the growing season, actual measurements differed significantly. Statistical analyses of results indicated that Tensiometer provided relatively accurate soil moisture data than $\mathrm{ECH}_{2} \mathrm{O}-5 \mathrm{TE}$ and Watermark without site-specific calibration. While $\mathrm{ECH}_{2} \mathrm{O}-5 \mathrm{TE}$ overestimated the soil water content, Watermark and Tensiometer underestimated. Results of this study suggested poor accuracy of
\end{abstract}

G. K. Ganjegunte $(\bowtie)$ J. A. Clark

Department of Soil and Crop Sciences, Texas Agrilife Research Center at El Paso, The Texas A\&M University System, 1380 A\&M Circle, El Paso, TX 79927-5020, USA

e-mail: GKGANJEGUNTE@ag.tamu.edu

\section{Z. Sheng}

Department of Biological and Agricultural Engineering,

Texas Agrilife Research Center at El Paso,

The Texas A\&M University System, 1380 A\&M Circle,

El Paso, TX 79927-5020, USA all three sensors if factory calibration and reported soil water retention curve for study site soil texture were used. This indicated that sensors needed site-specific calibration to improve their accuracy in estimating soil water content data.

Keywords Arid regions - Freshwater conservation . Irrigated pecans - Irrigation scheduling - Real time soil moisture data $\cdot$ Soil moisture sensors - Water scarcity
Abbreviations
AWC Available water content
EC Electrical Conductivity
FC Field water capacity
MAD Maximum available depletion
PWP Permanent wilting point
SAR Sodium adsorption ratio

\section{Introduction}

Pecan [Carya illinoinensis (Wangenh.) C. Koch] is a major irrigated cash crop in the El Paso region in Texas (Ganjegunte et al. 2011). Texas and New Mexico (mainly Dona Ana County) states are among the major producers of pecans in the US with about 32,000 and $34,000 \mathrm{Mg}$ of nut production in 2007, respectively (U.S. Department of Agriculture 2010). El Paso County has about 3,500 ha under pecan and ranked as the third largest county in terms of area under the crop in Texas (U.S. Department of Agriculture 2010). Pecan trees require large amounts of water for their growth and depth of irrigation water applied varies widely within the region ranging from 1.1 
to $3.1 \mathrm{~m}$ per year (Miyamoto 1983; Sorensen and Jones 1999; Sammis et al. 2004; personal observations by authors). Border irrigation, a type of flood irrigation wherein water is applied to leveled orchard plots divided by soil ridges from a field irrigation ditch at its upper end, is the oldest and most common irrigation method used in the region.

At present, most pecan growers base their irrigation scheduling on intuition or by counting the calendar days since the last irrigation. This method of irrigation scheduling can lead to over irrigation. Over irrigation not only results in loss of water to deep drainage but also increase leaching of nutrients into groundwater. According to Miyamoto (1983), consumptive water use of mature pecan trees range from 1 to $1.3 \mathrm{~m}$ per year. This suggests that there is an opportunity for considerable water savings by improving water use efficiency. Conserving freshwater is the top most priority in rapidly urbanizing extremely arid regions such as El Paso, Texas. Due to elevated salinity of irrigated soils in the Trans-Pecos basin there is very little scope for adopting other efficient methods of irrigation such as sprinkler or drip to conserve freshwater (Michelsen et al. 2009). Thus, improved irrigation scheduling can be the main method to improve water use efficiency and promote on-farm water conservation.

Instead of counting number of days, growers can improve water use efficiency by better timing their irrigation using soil water sensors. At present, many types of sensors that can provide real time continuous soil water data are available (Kallestad et al. 2006; Evett et al. 2009; Bittelli 2011; Pardossi and Incrocci 2011). About 57\% of the growers in the region use computers for farm business and many of these growers have access to internet (Kallestad et al. 2006). Soil water data from some of these inexpensive sensor systems can be downloaded wirelessly within the radio range (typically $1.6-4.8 \mathrm{~km}$ ), making data acquisition much easier for busy growers. This can make use of soil water sensors to time irrigation easier for many growers.

In the recent years, some new inexpensive sensors have been developed but their accuracy is not well known. In this study, we evaluated accuracy of three inexpensive types of soil water sensors (1) $\mathrm{ECH}_{2} \mathrm{O}-5 \mathrm{TE}$, a capacitance-based sensor manufactured by Decagon Devices Inc., Pullman, Washington, (2) Watermark 200SS, a resistivity-based granular matrix sensor, and (3) Tensiometer (model R) that measures soil water potential, both manufactured by Irrometer Co., Riverside, California (without site-specific calibration since such a requirement will likely to discourage potential farmers from adopting this technology) for their potential use in improved irrigation scheduling in a mature pecan orchard in West Texas.
Table 1 Daily evapotranspiration (ET $\mathrm{ET}_{\mathrm{o}}$ averaged for each month and monthly precipitation data with their coefficient of variation for the study site in the last 7 years (2004-2010)

\begin{tabular}{llllll}
\hline & $\mathrm{ET}_{\mathrm{o}}$ & & & \multicolumn{2}{l}{ Precipitation } \\
\cline { 2 - 3 } \cline { 6 - 6 } \cline { 5 - 6 } & Mean $(\mathrm{cm})$ & $\mathrm{CV}(\%)$ & & Mean $(\mathrm{cm})$ & $\mathrm{CV}(\%)$ \\
\hline January & 0.22 & 41.4 & & 0.76 & 117.0 \\
February & 0.32 & 37.6 & & 0.86 & 125.5 \\
March & 0.49 & 29.8 & & 0.85 & 125.1 \\
April & 0.63 & 24.3 & & 1.05 & 118.3 \\
May & 0.70 & 18.3 & & 1.02 & 112.7 \\
June & 0.74 & 16.7 & & 1.35 & 122.5 \\
July & 0.64 & 23.4 & & 1.37 & 123.5 \\
August & 0.55 & 20.5 & & 1.37 & 123.5 \\
September & 0.44 & 22.5 & & 1.37 & 123.5 \\
October & 0.32 & 25.1 & & 1.37 & 123.5 \\
November & 0.23 & 37.8 & & 1.46 & 120.0 \\
December & 0.18 & 42.4 & & 1.68 & 121.3 \\
\hline
\end{tabular}

Source: Texas ET network

\section{Materials and methods}

Study site

This study was conducted in a 12 ha mature pecan field, located in the south El Paso in Texas, USA $\left(31^{\circ} 24^{\prime} 12^{\prime \prime} \mathrm{N}\right.$, $106^{\circ} 3^{\prime} 13^{\prime \prime} \mathrm{W}$ ). Study site Saneli silty clay loam as the dominant map unit [Clayey over sandy or sandy-skeletal, montmorillonitic (calcareous), thermic Vertic Torrifluvents] (U.S. Department of Agriculture-Natural Resources Conservation Service 2010). The study site is laser leveled and the soils are characterized by the presence $(2-10 \%)$ of calcite $\left(\mathrm{CaCO}_{3}\right)$ and gypsum (up to $2 \%$ ) at variable depths within the root zone. Weather data for the study site are available for the last 7 years from Texas ET Network (Table 1). Based on last 7 years data, the average annual potential evapotranspiration $\left(\mathrm{ET}_{\mathrm{o}}\right)$, precipitation, solar radiation, minimum and maximum temperatures at the study site are $1.84,0.15 \mathrm{~m}, 21.6 \mathrm{MJ} \mathrm{m}^{-2},-10$ and $41^{\circ} \mathrm{C}$, respectively. The long-term annual $\mathrm{ET}_{\mathrm{o}}$ and precipitation in the El Paso County is about 1.94 and $0.17 \mathrm{~m}$, respectively (Texas ET Network 2010).

Soil sampling and analysis

Soil samples from 37.5 to $52.5 \mathrm{~cm}$ depth (same pits were used for sensor installation) were collected, air dried, ground and passed through $2 \mathrm{~mm}$ sieve. Sub-samples were analyzed for select properties such as soil texture using hydrometer method (Gee and Or 2002); saturated paste electrical conductivity- $\mathrm{EC}_{\mathrm{e}}$ (Rhoades 1996); $\mathrm{pH}$ (Thomas 1996); and major cations- $\mathrm{Na}, \mathrm{Ca}$, and $\mathrm{Mg}$ concentrations 
using inductively coupled plasma spectrometry (Helmke and Sparks 1996; Suarez 1996). Sodium adsorption ratio (SAR) of the soil samples was calculated using the following equation (Essington 2003):

$\mathrm{SAR}=\mathrm{Na}^{+} /\left[\mathrm{Ca}^{2+}+\mathrm{Mg}^{2+}\right]^{0.5}$

where $\mathrm{Ca}, \mathrm{Mg}$, and $\mathrm{Na}$ represent millimolar concentrations of the respective ions.

Triplicate soil cores were collected at $45 \mathrm{~cm}$ depth from locations close to sensors to determine bulk density (Grossman and Reinsch 2002).

\section{Soil water sensors}

$\mathrm{ECH}_{2} \mathrm{O}$-5TE: These are capacitance sensors that take advantage of high permittivity of water and calculate the apparent moist soil dielectric constant or relative permittivity $(\varepsilon)$. The relative permittivity value for water is about 80 , for air it is 1 and for mineral soils the value ranges from 3 to 7 . Thus, higher water content in soils translates into higher $\varepsilon$. The volumetric soil water content $\left(\theta_{\mathrm{v}}\right)$ can be calculated using the following empirical calibration equation (Decagon Devices Inc. 2010).

$$
\begin{aligned}
\theta_{\mathrm{v}}\left(\mathrm{m}^{3} \mathrm{~m}^{-3}\right)= & 4.3 \times 10^{-6} \varepsilon^{3}-5.5 \times 10^{-4} \varepsilon^{2} \\
& +2.92 \times 10^{-2} \varepsilon-5.3 \times 10^{-2}
\end{aligned}
$$

where $\theta_{\mathrm{v}}$ is volumetric soil water content measured in $\mathrm{m}^{3} \mathrm{~m}^{-3}, \varepsilon$ is dielectric units obtained by dividing sensor output by 50 .

Watermark 200SS: This is an electrical resistance device in a gypsum wafer surrounded by a granular matrix material. Once buried in soil, it exchanges water with surrounding soil and equilibrates. As the soil dries, resistance measured by the sensor increases. The derivation of volumetric soil water content from Watermark sensors data is a two step process involving (1) conversion of resistivity readings to soil matric potential and (2) conversion of soil matric potential to volumetric soil water. The Watermark monitor software that comes with the datalogger (model $900 \mathrm{~m}$ ) converts the resistance readings of Watermark sensor to soil matric potential using the following equation developed by Shock et al. (1998):

$\psi_{\mathrm{m}}=-(4.093+3.213 R) /(1-0.009733 R-0.01205 T)$

where $\psi_{\mathrm{m}}$ is matric potential in kilopascals, $R$ is the resistance of the sensor in kilohms and $T$ is the soil temperature $\left({ }^{\circ} \mathrm{C}\right)$.

In addition to soil water sensor, the Watermark datalogger (model 900m) supports temperature sensor. The Watermark software uses soil temperature recorded by the temperature sensor for the conversion (average soil temperature for the irrigation season was $24^{\circ} \mathrm{C}$ at $45 \mathrm{~cm}$ ). Soil matric potential was converted to volumetric soil water using soil water retention curve reported by Kallestad et al. (2006) for clay loam soil in the Mesilla Valley in NM, a location close to the study site.

Irrometer: Irrometer (Tensiometer) measures soil water potential and comprises a tube filled with water attached to a ceramic cup on one end and a vacuum gauge on the other end. These sensors were installed with the ceramic cup in good contact with soil at the desired depth using a $2.5 \mathrm{~cm}$ auger. Good contact between the ceramic cup and soil was facilitated by filling the hole with soil slurry and pushing the Tensiometer into the hole. Tenisometer soil water potential values were converted to volumetric soil water using a soil water retention curve reported by Kallestad et al. (2006) for clay loam soil in the Mesilla Valley.

\section{Sensors accuracy}

Accuracy of different sensors was evaluated under both laboratory and field conditions. Soil samples from 37.5 to $52.5 \mathrm{~cm}$ depth saved from the pits excavated for installing sensors in study site were used for evaluating sensor performance in the laboratory. For each of the sensor types $\left(\mathrm{ECH}_{2} \mathrm{O}-5 \mathrm{TE}\right.$, Watermark and Irrometer), three replications of composited soil samples were packed into a plastic container of known volume to mimic field bulk density $\left(1.32 \mathrm{~g} \mathrm{~cm}^{-3}\right)$ in a plastic containers. Containers used for $\mathrm{ECH}_{2} \mathrm{O}-5 \mathrm{TE}$ and watermark sensors had the following dimension: $36 \mathrm{~cm}$ length $\times 30 \mathrm{~cm}$ width $\times 15 \mathrm{~cm}$ depth. Containers used for Tensiometers were $30 \mathrm{~cm}$ diameter $\times 36 \mathrm{~cm}$ deep.

Soil water content was adjusted to saturation and three sub-samples of saturated soil were collected from each of the containers to determine the soil gravimetric water $\left(\theta_{\mathrm{g}}\right)$ content (Topp and Ferre 2002). Sensors were inserted into their respective containers (total number of containers were $9=3$ sensors $\times 3$ replications). The weight of container with sensors at saturation was recorded. Containers were allowed to dry and weight of the container was recorded daily over 22 days for determining the $\theta_{\mathrm{g}}$ values. Container soil $\theta_{\mathrm{g}}$ values were converted to $\theta_{\mathrm{v}}$ using the average bulk density value for $45 \mathrm{~cm}$ depth. Daily $\theta_{\mathrm{v}}$ data were downloaded from data loggers connected to $\mathrm{ECH}_{2} \mathrm{O}-5 \mathrm{TE}$ and Watermark sensors and daily soil water potential readings were collected from Tensiometer over the 22 days duration. Accuracies of three different sensors were determined based on mean difference (Md) (Addiscott and Whitmore 1987), relative root mean square error, RRMSE and coefficient of determination $\left(R^{2}\right)$ (Loague and Green 1991) between the sensor $\theta_{\mathrm{v}}$ and that derived from $\theta_{\mathrm{g}}$. 
Field evaluation of soil water sensors

$\mathrm{ECH}_{2} \mathrm{O}-5 \mathrm{TE}$, Watermark, and Tensiometers were installed as per manufacturers' guidelines and sensor data were used without site-specific calibration to obtain $\theta_{\mathrm{v}}$, because the expected users (growers) are not likely to carry out sitespecific calibration of sensors. Such a need is likely to deter many growers from accepting sensors for irrigation scheduling. Three replications of each sensor were buried $2.5 \mathrm{~m}$ away from tree trunk (approximate mid-point between trunk and canopy) and at four depths $(15,20,45$ and $60 \mathrm{~cm}$ ). Soil samples from four depths were collected close to sensors at different times during the irrigation season to determine water content and evaluate sensor performance in the field. However, in this study data for $45 \mathrm{~cm}$ depth are reported because it represents the mid-point in pecan effective tree root zone. The $\mathrm{ECH}_{2} \mathrm{O}-5 \mathrm{TE}$ sensor was connected to a continuous data logger (model EM50), and Watermark sensor was connected to its data logger (model $900 \mathrm{~m}$ ). EM50 data logger was programmed to collect readings at 15 -min intervals and Watermark data logger $900 \mathrm{~m}$ collected readings at every 30 -min interval. Once the irrigation season started (April to October) data were downloaded from EM50 and $900 \mathrm{~m}$ data loggers manually once in every 15 days and Tensiometer readings were recorded daily. Sensor systems were enclosed in separate cages built using fence posts and wire mesh to protect from unintentional damage during farm operations.

Water applied to each replication plot was measured after each irrigation event during the study period. Since the irrigation ditches are lined with concrete and individual plots were irrigated in sequence, it was possible to measure amount of irrigation water applied fairly accurately. Amount of irrigation water applied at each irrigation event was measured by monitoring volume of irrigation water (flow rate in concrete lined irrigation ditches $x$ area of cross section of water $x$ duration of irrigation at each irrigation event).

\section{Results and discussion}

Study site soil properties

The average texture of the soil at $45 \mathrm{~cm}$ depth in the study site was clay loam (Table 2). Average saturated paste $\mathrm{pH}$, $\mathrm{EC}_{\mathrm{e}}$, and SAR of soil samples were 8.69, 3.17 $\mathrm{dS} \mathrm{m}^{-1}$, and $7 \mathrm{mmol}^{1 / 2} \mathrm{~L}^{-1 / 2}$, respectively. Although mean $\mathrm{Ca}, \mathrm{Mg}$, and $\mathrm{Na}$ concentrations were 210,44 , and $359 \mathrm{mg} \mathrm{L}^{-1}$, respectively, there were large variations within the study site. Variations in $\mathrm{Ca}, \mathrm{Mg}$, and $\mathrm{Na}$ concentrations in the soil can be attributed to the presence of native calcite or gypsum that might had some $\mathrm{Mg}$ impurities and quality of irrigation water (U.S. Department of Agriculture-Natural
Table 2 Select properties of soil samples collected close to the sensors at $45 \mathrm{~cm}$ depth

\begin{tabular}{llll}
\hline Parameter & Mean & $\forall$ & SD \\
\hline Clay $\left(\mathrm{g} \mathrm{kg}^{-1}\right)$ & 366 & $\forall$ & 15 \\
Sand $\left(\mathrm{g} \mathrm{kg}^{-1}\right)$ & 400 & $\forall$ & 25 \\
Silt $\left(\mathrm{g} \mathrm{kg}^{-1}\right)$ & 233 & $\forall$ & 12 \\
Texture & \multicolumn{2}{l}{ Clay loam } \\
$\mathrm{pH}$ & 8.69 & $\forall$ & \\
EC $\left(\mathrm{dS} \mathrm{m}^{-1}\right)$ & 3.17 & $\forall$ & 0.14 \\
Sodium adsorption ratio $\left(\mathrm{mmol}^{1 / 2} \mathrm{~L}^{-1 / 2}\right)$ & 7 & $\forall$ & 5 \\
Ca $\left(\mathrm{mg} \mathrm{L}^{-1}\right)$ & 210 & $\forall$ & 246 \\
Mg $\left(\mathrm{mg} \mathrm{L}^{-1}\right)$ & 44 & $\forall$ & 45 \\
Na $\left(\mathrm{mg} \mathrm{L}^{-1}\right)$ & 359 & $\forall$ & 267 \\
Bulk density $\left(\mathrm{Mg} \mathrm{m}^{-3}\right)$ & 1.32 & $\forall$ & 0.05 \\
\hline
\end{tabular}

Resources Conservation Service 2010). Bulk density of study site soil at $45 \mathrm{~cm}$ depth ranged from 1.2 to $1.4 \mathrm{Mg}$ $\mathrm{m}^{-3}$, with an average of $1.32 \mathrm{Mg} \mathrm{m}^{-3}$. These values are within the range of 1.25 to $1.50 \mathrm{Mg} \mathrm{m}^{-3}$ reported for the study site soils by USDA-NRCS (2010).

\section{Sensor accuracy}

Relationship between $\theta_{\mathrm{v}}$ data from sensors in the laboratory and $\theta_{\mathrm{v}}$ determined from container $\theta_{\mathrm{g}}$ is provided in Fig. 1 . Details of the statistical comparison of the sensors performance are presented in Table 3. The positive Md value suggested that $\mathrm{ECH}_{2} \mathrm{O}-5 \mathrm{TE}$ overestimated the soil water content, while negative $\mathrm{Md}$ values for Watermark and Tensiometer indicated they both underestimated the soil water content. While the $\mathrm{ECH}_{2} \mathrm{O}-5 \mathrm{TE}$ overestimated soil water content by $0.031 \mathrm{~m}^{3} \mathrm{~m}^{-3}$, Watermark underestimated it by $0.036 \mathrm{~m}^{3} \mathrm{~m}^{-3}$, and Tensiometer by $0.025 \mathrm{~m}^{3} \mathrm{~m}^{-3}$. All three sensors had Md value that were significantly different from zero, indicating $\theta_{\mathrm{v}}$ derived from sensors were statistically different from $\theta_{\mathrm{v}}$ derived from $\theta_{\mathrm{g}}$. Tensiometer that had the least RRMSE and Md among three sensors, indicating it measured soil water content relatively more accurately than other two sensors. Relatively higher RRMSE for $\mathrm{ECH}_{2} \mathrm{O}-5 \mathrm{TE}$ and Watermark could be due to poor calibration. Tensiometer and $\mathrm{ECH}_{2} \mathrm{O}-$ 5TE sensors had greater coefficient of determination $\left(R^{2}\right)$ than that of Watermark. This indicated that precision of Watermark was lower than the other two sensors evaluated in this study. Coefficient of determination between $\theta_{\mathrm{v}}$ derived from sensors and $\theta_{\mathrm{v}}$ determined based on gravimetric soil water were highly significant at $P<0.01$. Intercept and slope of regression equations for all three sensors indicated that site-specific calibration would have increased the precision of sensors significantly.

Field measurements of irrigation water indicated that all three plots received same amount of water of about $1.68 \mathrm{~m}$ 

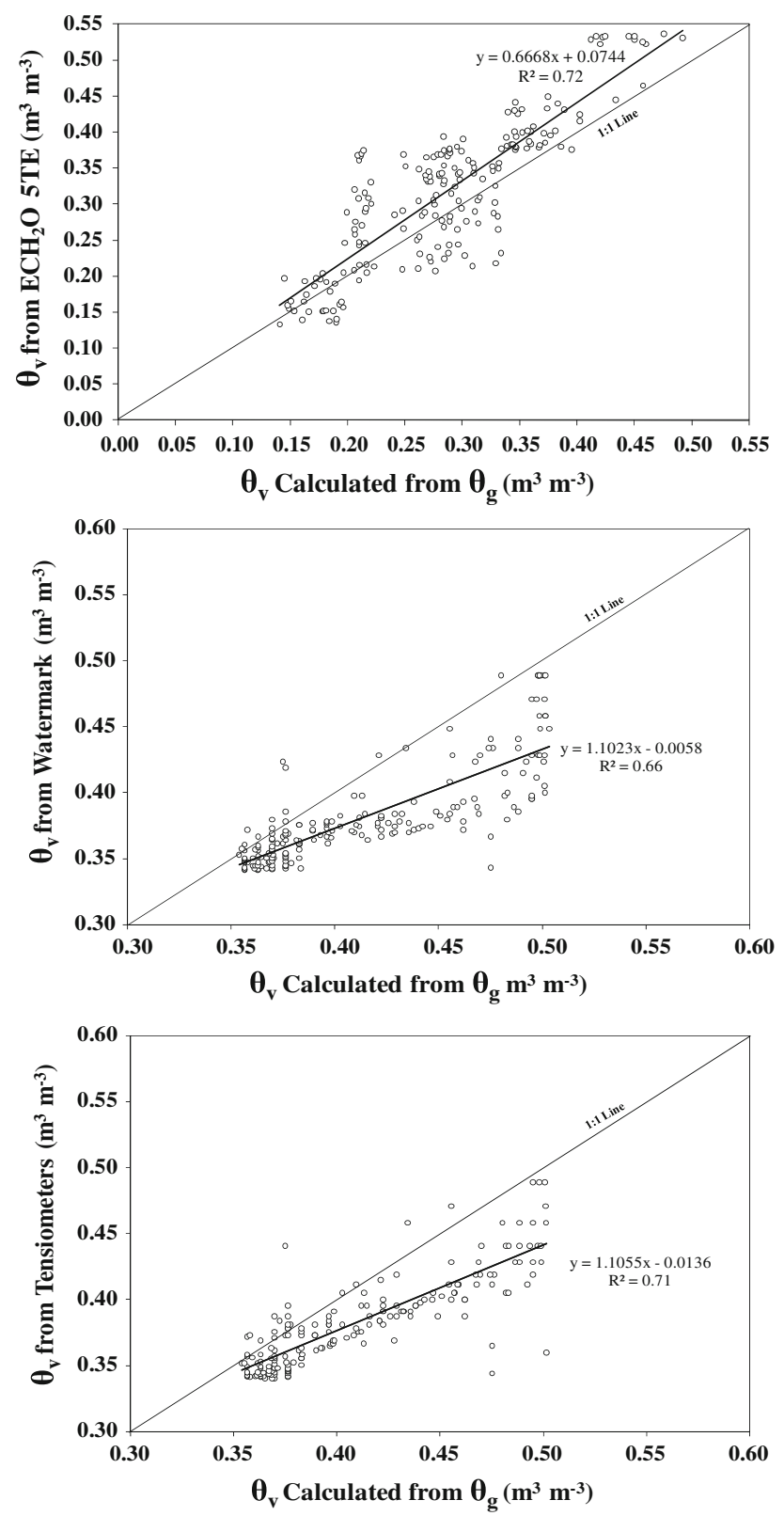

Fig. 1 Comparison between soil water content measurements $\left(\theta_{\mathrm{v}}, \mathrm{m}^{3} \mathrm{~m}^{-3}\right)$ by $\mathrm{ECH}_{2} \mathrm{O}-5 \mathrm{TE}$, Watermark and Tensiometer sensor and $\theta_{\mathrm{v}}$ determined from gravimetric soil water content under laboratory conditions

Table 3 Statistical summary of sensor performance

\begin{tabular}{lclrll}
\hline Sensor & ${\mathrm{Md}\left(\mathrm{m}^{3} \mathrm{~m}^{-3}\right)}$ & RRMSE $(\%)$ & Intercept & Slope & $R^{2}$ \\
\hline ECH $_{2}$ O 5TE & 0.031 & 28.9 & 0.074 & 0.67 & 0.72 \\
Watermark & -0.036 & 12.8 & -0.037 & 1.19 & 0.66 \\
Tensiometer & -0.025 & 9.7 & 0.013 & 1.04 & 0.71 \\
\hline
\end{tabular}

during the study period, which was applied in twelve irrigations. This value lies well within the range reported by past studies on pecan irrigation in the region (Kallestad

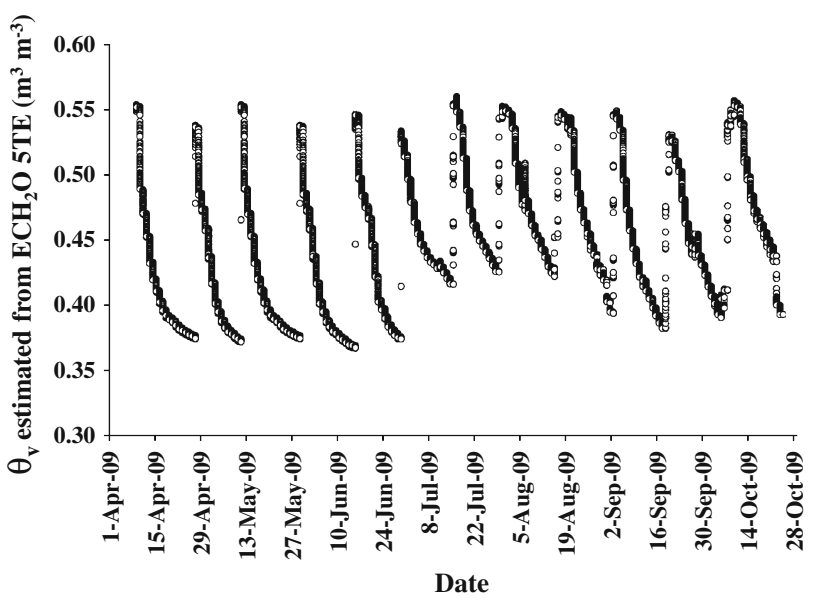

Fig. 2 Field soil water content $\left(\theta_{\mathrm{v}}, \mathrm{m}^{3} \mathrm{~m}^{-3}\right)$ trends measured by $\mathrm{ECH}_{2} \mathrm{O}-5 \mathrm{TE}$

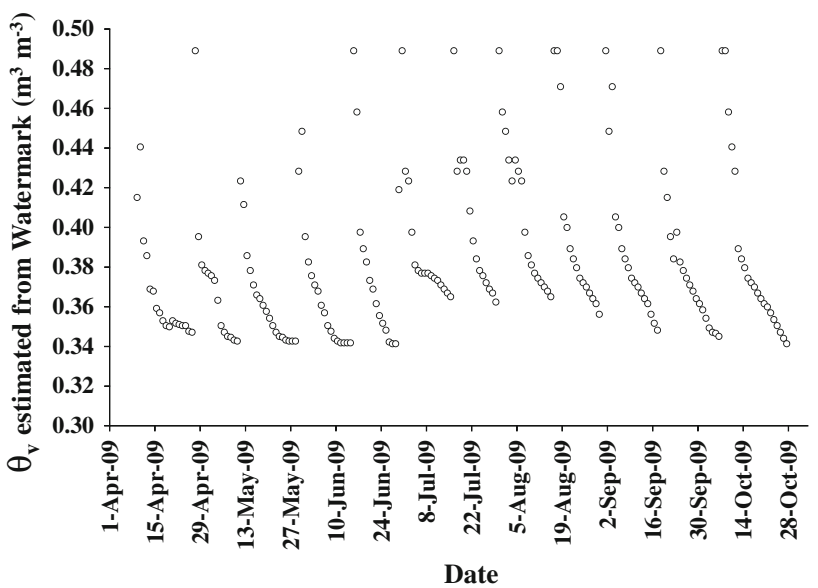

Fig. 3 Field soil water content $\left(\theta_{\mathrm{v}}, \mathrm{m}^{3} \mathrm{~m}^{-3}\right)$ trends measured by Watermark

et al. 2006). The $\theta_{\mathrm{v}}$ data measured by $\mathrm{ECH}_{2} \mathrm{O}-5 \mathrm{TE}$, Watermark, and Tensiometers in the field are presented in Figs. 2, 3 and 4, which indicated that the sensors captured all the irrigation events during the study period. While all the three sensors captured the general trends in soil water content, the actual sensor readings varied by as much as $0.06 \mathrm{~m}^{3} \mathrm{~m}^{-3}$ at any given measurement date. In this study, factory calibration and reported soil water retention curve were used to obtaining soil water content from the sensors. Thus, without site-specific calibration, it is hard to get accurate data on soil water content. Figure 5 shows the performance of three sensors in the field, which confirmed the results of the laboratory testing of these sensors. In the field, Watermark had the least precision and $R^{2}$ of Tensiometer was lower than that obtained in laboratory, probably due to subtle variations in soil texture.

Field data confirmed the overestimation of $\theta_{\mathrm{v}}$ by $\mathrm{ECH}_{2} \mathrm{O}-5 \mathrm{TE}$ and underestimation of the same by Watermark and Tensiometers. For example, for a soil with an 


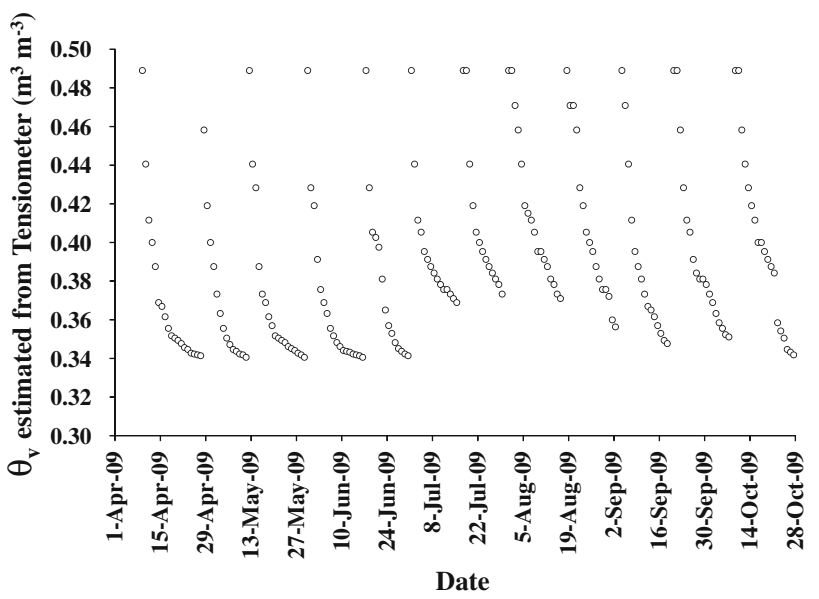

Fig. 4 Field soil water content $\left(\theta_{\mathrm{v}}, \mathrm{m}^{3} \mathrm{~m}^{-3}\right)$ trends measured by Tensiometer

average BD of $1.32 \mathrm{~g} \mathrm{~cm}^{-3}$ the expected porosity of soil would be about $50 \%$. Figures 2, 3 and 4 showed that the $\theta_{\mathrm{v}}$ values by $\mathrm{ECH}_{2} \mathrm{O}-5 \mathrm{TE}$ were always greater than $50 \%$ immediately after an irrigation event (when all pores are saturated with water) and other two sensors reported $\theta_{\mathrm{v}}$ values lower than the expected $50 \%$.

In this study factory calibration values were used for $\mathrm{ECH}_{2} \mathrm{O}-5 \mathrm{TE}$ and reported soil retention curve for clay loam soil in Mesilla Valley. Overestimation of soil moisture content by sensor can occur if study site soil has greater finer (silt and clay) particle contents for a given texture classification. The factory calibration was probably based on soil having a median clay content of the range for clay loam classification. Under estimation of soil water content as seen in case of Watermark and Tensiometers may be due to study site soils having less clay than that of soil used for developing retention curve by Kallestad et al. (2006) for the same clay loam classification.

Past studies have indicated poor performances of Watermark and Tensiometers when factory calibration equations were used (Paramasivam et al. 2000; MunozCarpena et al. 2005; Thompson et al. 2006). Rosenbaum et al. (2010) in a study that compared $\mathrm{ECH}_{2} \mathrm{O}$, EC-5, $\mathrm{ECH}_{2} \mathrm{O}-\mathrm{TE}$, and $\mathrm{ECH}_{2} \mathrm{O}-5 \mathrm{TE}$ sensors concluded that an improvement in accuracy of nearly $0.01 \mathrm{~cm}^{3} \mathrm{~cm}^{-3}$ can be reached in the high-permittivity range for each sensor type by calibrating each sensor individually. Cardenas-Lailhacar and Dukes (2010) reported a highly significant correlation between $\theta_{\mathrm{v}}$ measured by $\mathrm{ECH}_{2} \mathrm{O}-20$ probe (an older version than $\mathrm{ECH}_{2} \mathrm{O}-5 \mathrm{TE}$ ) and Watermark sensors but observed decreasing correlation with increasing irrigation frequency. They further concluded that Watermark sensors were less accurate and consistent in measuring $\theta_{\mathrm{v}}$ especially in the wetter range of soil water than Acclima time domain transmissometry sensor (Acclima Inc., ID) and a resistivity sensor manufactured by Rain Bird (Rain Bird Inc., CA).
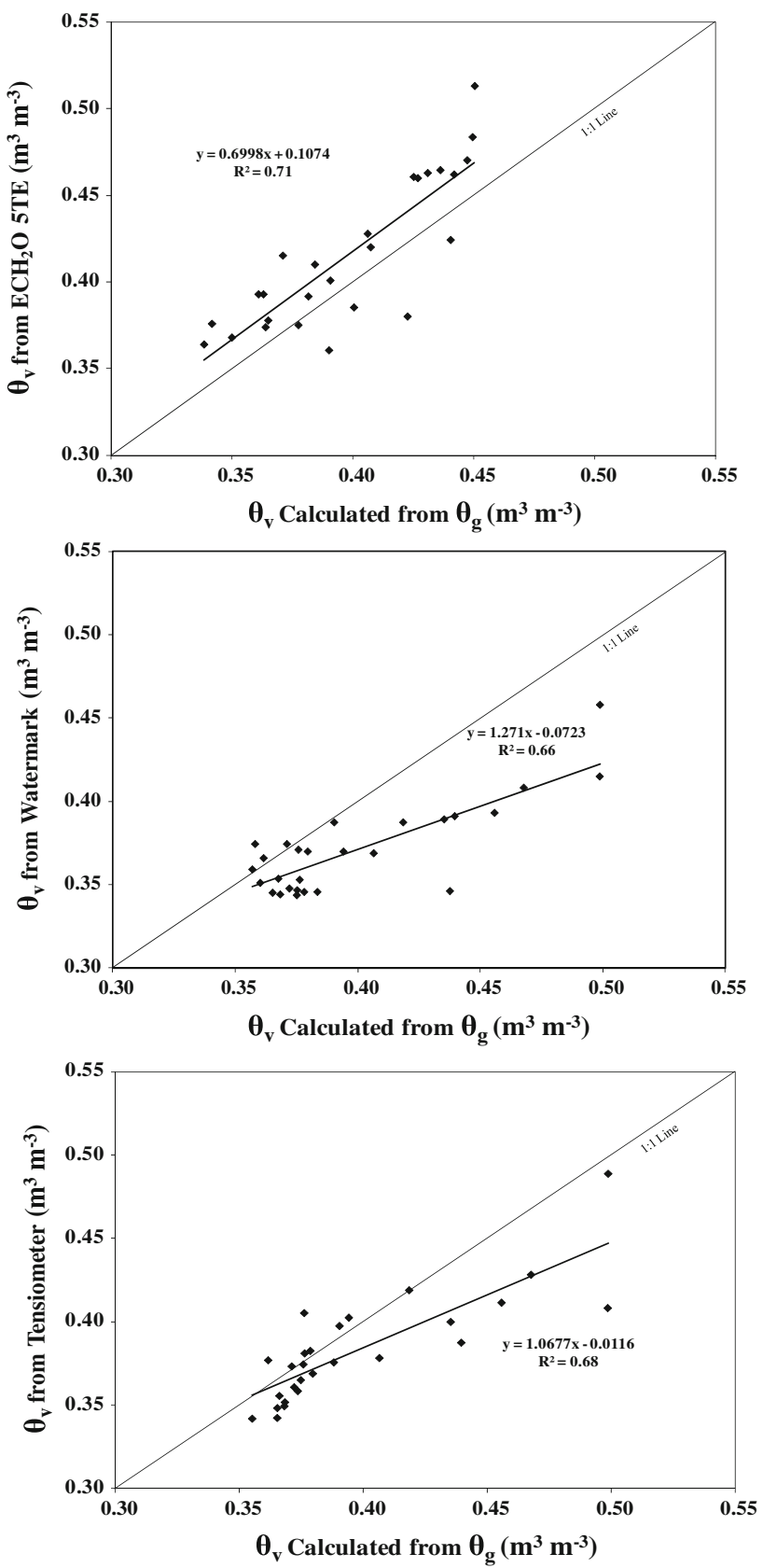

Fig. 5 Comparison between soil water content measurements $\left(\theta_{\mathrm{v}}, \mathrm{m}^{3} \mathrm{~m}^{-3}\right)$ by $\mathrm{ECH}_{2} \mathrm{O}-5 \mathrm{TE}$, Watermark and Tensiometer sensor and $\theta_{\mathrm{v}}$ determined from gravimetric soil water content under field conditions

Thus, it is clear from the above discussion that all the three sensors performed poorly under both laboratory and field observations without site-specific calibration.

\section{Conclusions}

Overall three sensors captured the general trends of soil water content. Amount of irrigation water applied was 
within the range reported for pecan in the region by past studies. However, both Tensiometer and Watermark underestimated soil water content while $\mathrm{ECH}_{2} \mathrm{O}-5 \mathrm{TE}$ sensor overestimated the same. Tensiometer registered relatively lower Md, lower RRMSE, and relatively higher coefficient of determination between sensor $\theta_{\mathrm{v}}$ and that calculated from $\theta_{\mathrm{g}}$, than the other two sensors. This indicated that Tensiometer provided relatively more accurate soil water data compared to Watermark 200SS, and $\mathrm{ECH}_{2} \mathrm{O}-5 \mathrm{TE}$. Accuracy of three sensors with just factory calibration was lower than the ideal level (low Md and RRMSE and high $R^{2}$ ) for obtaining accurate soil water data. Results of the study suggested that accuracy of sensors can be greatly improved by site-specific calibration.

Acknowledgments This project was in part funded by the Efficient Irrigation for Water Conservation in the Rio Grande Basin project supported by the National Institute of Food and Agriculture, U.S. Department of Agriculture, under Agreement No. 2009-34461-19772. We thank Art Ivey for facilitating access to the study site. Technical assistance from Robert Braun, Yi Liu, Elias Montoya, Amy Eddins, Oscar Guerrero, Enrique Garcia, and Julian Moreno is greatly appreciated. The Funding Agency is NIFA-USDA.

Open Access This article is distributed under the terms of the Creative Commons Attribution License which permits any use, distribution, and reproduction in any medium, provided the original author(s) and the source are credited.

\section{References}

Addiscott TM, Whitmore AP (1987) Computer simulation of changes in soil mineral nitrogen and crop nitrogen during autumn, winter, and spring. J Agric Sci 107:141-157. doi:10.1017/S002185 9600081089

Bittelli M (2011) Measuring soil water content: a review. HortTechnology 21:293-300

Cardenas-Lailhacar B, Dukes MD (2010) Precision of soil moisture sensor irrigation controllers under field conditions. Agric Water Manage 97:666-672. doi:10.1016/j.agwat.2009.12.009

Decagon Devices Inc (2010) Calibration equations for the $\mathrm{ECH}_{2} \mathrm{O}$ EC-5-ECH $\mathrm{H}_{2} \mathrm{O}$-TE-and $\mathrm{ECH}_{2} \mathrm{O}-5 \mathrm{TE}$ sensors. Available online at http://www.decagon.com/assets/ Uploads/Calibration-Equationsfor-the- $\mathrm{ECH}_{2} \mathrm{O}-\mathrm{EC}-5$ - $\mathrm{ECH}_{2} \mathrm{O}$-TE-and- $\mathrm{ECH}_{2} \mathrm{O}-5 \mathrm{TE}-\mathrm{Sensors}$.pdf. Accessed on April 21, 2010

Essington ME (2003) Soil and water chemistry: an integrative approach. CRC Press, Boca Raton

Evett SR, Schwartz RC, Tolk JA, Howell TA (2009) Soil profile water content determination: spatiotemporal variability of electromagnetic and neutron probe sensors in access tubes. Vadose Zone J 8:926-941. doi:10.2136/vzj2008.0146

Ganjegunte GK, Sheng Z, Braun R (2011) Salinity management using an anionic polymer in a pecan field with calcareous-sodic soil. J Environ Qual 40:1314-1321

Gee GW, Or D (2002) Particle size analysis. In: Dane JH, Topp GC (eds) Methods of soil analysis. Part 4. Physical methods. SSSA Book Ser. 5. SSSA, Madison, pp 255-293

Grossman RB, Reinsch TG (2002) Bulk density and linear extensibility. In: Dane JH, Topp GC (eds) Methods of soil analysis. Part 4. Physical methods. SSSA Book Ser. 5. SSSA, Madison, pp 201-228
Helmke PA, Sparks DL (1996) Lithium, sodium, potassium, rubidium, and cesium. In: Sparks DL et al (eds) Methods of soil analysis. Part 3. Chemical methods. SSSA Book Ser. 5. SSSA, Madison, pp 551-574

Kallestad JC, Sammis TW, Mexal JG, White J (2006) Monitoring and management of pecan orchard irrigation: a case study. HortTechnology 16:667-673

Loague K, Green RE (1991) Statistical and graphical methods for evaluating solute transport models: overview and applications. J Contam Hydrol 7:51-73. doi:10.1016/0169-7722(91)90038-3

Michelsen AM, Chavez M, Lacewell R, Gilley J, Sheng Z (2009) Evaluation of irrigation efficiency strategies for far west Texas: Feasibility, water savings and cost considerations. Texas Water Resources Institute, Technical Report No. 360

Miyamoto S (1983) Consumptive water use of irrigated pecans. J Am Soc Hort Sci 108:676-681

Munoz-Carpena R, Dukes MD, Li YC, Klassen W (2005) Field comparison of tensiometer and granular matrix sensor automatic drip irrigation on tomato. HortTechnology 15:584-590

Texas ET Network (2010) Available at http://texaset.tamu.edu/ pet.php. Accessed on 31 March 2011)

Paramasivam S, Alva AK, Fares A (2000) An evaluation of soil water status using tensiometers in a sandy soil profile under citrus production. Soil Sci 165:343-353

Pardossi A, Incrocci L (2011) Traditional and new approaches to irrigation scheduling in vegetable crops. HortTechnology 21:309_ 313

Rhoades JD (1996) Salinity: electrical conductivity and total dissolved solids. In: Sparks DL et al (eds) Methods of soil analysis. Part 3. Chemical methods. SSSA Book Ser. 5. SSSA, Madison, pp 417-436

Rosenbaum U, Huisman JA, Weuthen A, Vereecken H, Bogena HR (2010) Sensor-to-sensor variability of the $\mathrm{ECH}_{2} \mathrm{O}$ EC-5, TE, and $\mathrm{ECH}_{2} \mathrm{O}-5 \mathrm{TE}$ sensors in dielectric liquids. Vadose Zone $\mathrm{J}$ 9:181-186. doi:10.2136/vzj2009.0036

Sammis TW, Mexal JG, Miller D (2004) Evapotranspiration of flood irrigated pecans. Agric Water Manage 69:179-190. doi:10.1016/j. agwat.2004.05.005

Shock CC, Barnum JM, Seddigh M (1998) Calibration of watermark soil moisture sensors for irrigation management. In: Irr Assn Proc Intl Irr Show, San Diego, pp 139-146

Sorensen RB, Jones TL (1999) Soil water uptake pattern of pecan trees grown in coarse gravelly soils. HortTechnology 9:402-408

Suarez DL (1996) Beryllium, magnesium, calcium, strontium and barium. In: Sparks DL et al (eds) Methods of soil analysis. Part 3. Chemical methods. SSSA Book Ser. 5. SSSA, Madison, pp 575-602

Thomas GW (1996) Soil pH and soil acidity. In: Sparks DL et al (eds) Methods of soil analysis. Part 3. Chemical methods. SSSA Book Ser. 5. SSSA, Madison, pp 475-490

Thompson RB, Gallardo M, Agilera T, Valdez LC, Fernandez MD (2006) Evaluation of watermark sensor for use with drip irrigated vegetable crops. Irrig Sci 24:185-202. doi:10.1007/s00271005-0009-5

Topp GC, Ferre PA (2002) Water content by thermo-gravimetric method using convective oven-drying. In: Dane JH, Topp GC (eds) Methods of soil analysis. Part 4. Physical methods. SSSA Book Ser. 5. SSSA, Madison, pp 419-420

U.S. Department of Agriculture (2010) 2007 Census of agriculture. Available online at http://www.agcensus.usda.gov/Publications/ 2007/Full_Report/Volume_1,_Chapter_2_County_Level/Texas/ st48_2_031_031.pdf. Accessed on 21 March 2011

U.S. Department of Agriculture-Natural Resources Conservation Service (2010) Web based soil survey report for study site in El Paso County, TX. Available at http://websoilsurvey.nrcs.usda. gov/app/WebSoilSurvey.aspx. Accessed on 21 March 2011 